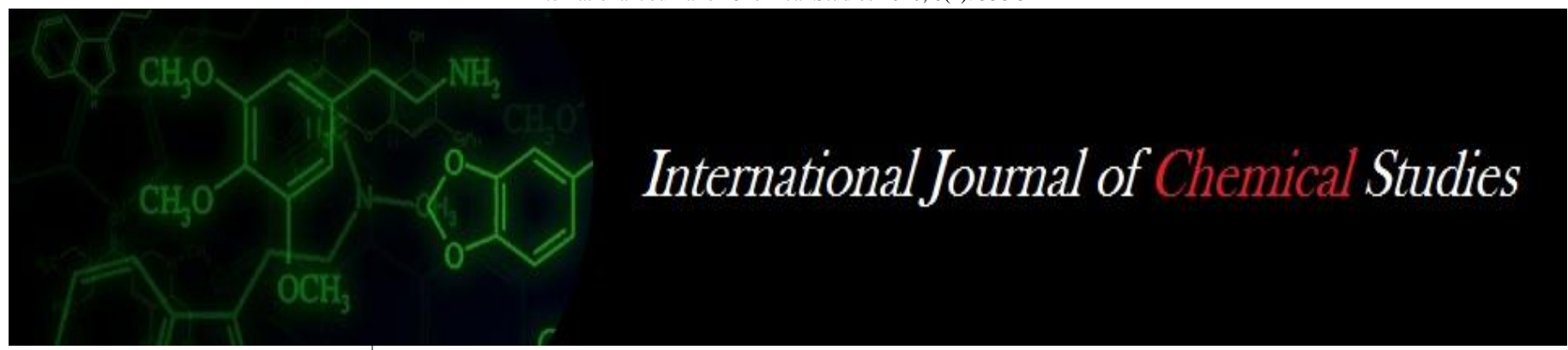

P-ISSN: 2349-8528

E-ISSN: 2321-4902

www.chemijournal.com

IJCS 2020; 8(2): 538-541

(C) 2020 IJCS

Received: 15-01-2020

Accepted: 18-02-2020

Manish Kumar

SRF, ICAR-Central Institute of

Agricultural Engineering,

Bhopal, Madhya Pradesh, India

Janak Ghodasara

SRF, ICAR-Central Institute of

Agricultural Engineering,

Bhopal, Madhya Pradesh, India

\section{Energy and economic assessment of manual and self-propelled rice transplanter}

\section{Manish Kumar and Janak Ghodasara}

DOI: https://doi.org/10.22271/chemi.2020.v8.i2h.8823

\begin{abstract}
The energy and economic investigating of self-propelled rice transplanter and manually method of rice transplanting in the area of Sonpur, Chhattisgarh. The energy consumption for rice transplanting calculated by the use of standard formulas and the cost economy intended with the standard method. The data was collected with the reference of the field performance of different method of rice cultivation. Self-propelled rice transplanter has consumed $210 \mathrm{MJ} / \mathrm{ha}$ energy whereas the manual method consumes $470 \mathrm{MJ} / \mathrm{ha}$ energy. The cost of rice transplanting was Rs. 1145 and Rs. 6000 for self-propelled and manually method respectively.
\end{abstract}

Keywords: Transplanting, energy, cost-economics, self-propelled

\section{Introduction}

Rice (Oryza-sativa) is one of the most important crops of India growing over an area of 43.2mha with the production of $110 \mathrm{Mt}$ according to the annual report 2017-18, Ministry of Agriculture and Farmer Welfare, GoI. The demand for rice in India to be increased 156 Mt by 2030. (ICAR, 2010). Harvesting of the rice in Chhattisgarh is in around 3.61mha with a production of $5.48 \mathrm{Mt}$ and a productivity of $1517 \mathrm{~kg}$ per ha. Chhattisgarh is popularly known as the "Rice Bowl" of India. To meet the demand of rice is the major challenge for our government and scientist of India. The demand of rice is to be fulfilled by producing more rice in less land, optimum use of the energy inputs and farm mechanization (Jain et al., 2019) ${ }^{[11]}$.

The energy requirement in the agricultural sector depends on the level of mechanization, cropping pattern, climatic condition, size of land and types of soil. All of them the mechanization is perform the lead role in agricultural energy management. Agriculture uses large quantities of locally available non-commercial energy, such as manure and animal energy, and commercial energy, directly and indirectly in the form of seed, diesel, electricity, fertilizer, plant protection chemicals, irrigation water, machinery, etc. (Singh, 2002; Alam et al., 2005) ${ }^{[2,3]}$.

Manual transplanting is tedious, tiresome and labour consuming because a person has to stand in a puddled field and bending posture for many hours for putting seedling into the soil by hand. Manual transplanting is one of the labour-intensive operation comprising of nursery raising, uprooting of the seedlings and transplanting them in the main field, with total labour requirement of about 280-350 man-hours/ha. Some of the postures, taken by them were very harmful, but they were compelled to adopt those postures during work for a long time. During transplanting, the workers adopt a strongly bent posture in the muddy field for a long time. In all the tasks of rice cultivation are repetitive. So that the manually transplanting consuming more energy to transplant the rice plant (Guru et al., 2018) ${ }^{[4]}$. The appropriate mechanization coupled with skill operators gives high productivity in agriculture. Mechanization means the introduction of impressed tools and implements that increase production and productivity with reduce the unit cost of production without drudgery and reducing the time of production. Mechanization can reduce the energy requirement into the farm who consumed by the labours (Dave et al., 2000) ${ }^{[5]}$.

In this study, we calculated the energy input in the operation of transplanting for the production of rice in the area of Sonpur, Block-Patan, District-Durg, and Chhattisgarh. To compare the energy consumption and cost economics in self-propelled rice transplanter and manually transplanting with objective of the energy and cost of the rice transplanting.
Corresponding Author:

Manish Kumar

SRF, ICAR-Central Institute of

Agricultural Engineering,

Bhopal, Madhya Pradesh, India 


\section{Methodology}

The study was conducted at the farm of the Sonpur village. The field performance of the self-propelled 8-row transplanter was evaluated. In terms of overall dimensions, weight of the machine, planting speed, row to row and plant to plant spacing was evaluated and calculating. The technical specification of self-propelled rice transplanter is shown in Table-1.

\section{Energy Calculation}

The energy input of both mechanical and manually operation of rice transplanting was calculating using relevant energy equivalent shown in Table-2. The data was converted into a suitable energy unit and express in $\mathrm{MJ} / \mathrm{ha}$. The following formulas were used for energy calculation. (Nguyen et al., 2016) ${ }^{[10]}$

- Fuel Energy-

- $\mathrm{E}_{\text {fuel }}=\mathrm{h} \times \mathrm{FC} \times \mathrm{FE}_{\mathrm{q}}$

- Labour energy-

- $\mathrm{E}_{\text {labour }}=\left(\right.$ No. of labour $\times$ Time $\left.\times \mathrm{H}_{\mathrm{q}}\right) /$ Area

- Machine Energy-

- $\mathrm{E}_{\text {machine }}=\left(\mathrm{W} \times \mathrm{ME}_{\mathrm{q}} \times \mathrm{h}\right) / \mathrm{L}$

Table 1: Technical specification of self-propelled rice transplanter

\begin{tabular}{|c|c|}
\hline Model & $\begin{array}{c}\text { Yanji Shakti 8 row self- propelled } \\
\text { rice transplanter; Model 2 ZT-238-8 }\end{array}$ \\
\hline Overall dimension L x W x H (mm) & $2410 \times$ 2290 x 1200 \\
\hline Weight $(\mathrm{kg})$ & 320 \\
\hline Power unit & $\begin{array}{c}2.94 \mathrm{KW}(4 \mathrm{HP}) \text { single cylinder air } \\
\text { cooled diesel engine }\end{array}$ \\
\hline Planting speed $(\mathrm{km} / \mathrm{h})$ & $1-2$ \\
\hline Road traveling speed $(\mathrm{km} / \mathrm{h})$ & 8.2 \\
\hline Number of rows & 8 \\
\hline Row spacing (mm) & 238 \\
\hline Distance between hill $(\mathrm{mm})$ & $140-170$ \\
\hline Growing density of seedlings \\
hills $/ \mathrm{m}^{2}$ & $34-42$ \\
\hline No. of seedlings per hill, (adjustable) & $3-8$ \\
\hline Width of seedling mat $(\mathrm{cm})$ & 22 \\
\hline Planting depth, $\left(\mathrm{cm}^{2}\right.$ adjustable $)$ & $2-6$ \\
\hline Capacity $\left(\mathrm{m}^{2} / \mathrm{h}\right)$ & $1300-2000$ \\
\hline
\end{tabular}

Where, $E_{\text {fuel, }}$ direct fuel energy use, MJ/ha; h, working hours per operation, h/ha; FC, average fuel consumption, $1 ; \mathrm{FE}_{\mathrm{q}}$, fuel energy equivalent, $\mathrm{MJ} / \mathrm{l} . \mathrm{H}_{\mathrm{q}}$, human energy equivalent. $\mathrm{W}$, total weight of machine, $\mathrm{kg} ; \mathrm{ME}_{\mathrm{q}}$, machine energy equivalent, $\mathrm{MJ} / \mathrm{kg}$; L, life of machine, $\mathrm{hr}$.

The fuel energy was calculated with measured fuel consumption and actual field capacity of the machine. The machine energy was estimated by the total weight of machine, a life of machine and total operating hour per operation.
Table 2: Energy equivalence of different inputs and outputs

\begin{tabular}{|c|c|c|}
\hline Particulars & $\begin{array}{c}\text { Energy equivalent } \\
\text { (MJ/unit) }\end{array}$ & References \\
\hline Human labour (h) & 1.96 & $\begin{array}{c}(\text { Tabar } \text { et al. 2010 })^{[9]} \\
(\text { Mobtaker } \text { et al., 2010) }\end{array}$ \\
\hline Diesel (1) & 56.31 & $\begin{array}{c}\text { (Mobtaker } \text { et al., 2010) } \\
{\left[{ }^{[8]}\left(\text { Kumar } \text { et al., 2018) }{ }^{[4]}\right.\right.}\end{array}$ \\
\hline $\begin{array}{l}\text { Farm machinery (Excluding } \\
\text { self-propelled) }(\mathrm{kg})\end{array}$ & 62.7 & \begin{tabular}{|} 
(Mobtaker et al., 2010) ${ }^{[8]}$, \\
$($ Pradhan et al., 2015)
\end{tabular} \\
\hline
\end{tabular}

\section{Cost Economics}

The economic analysis of self-propelled rice transplanter was calculated according to (Kamboj et al., 2012) ${ }^{[12]}$.

\section{A. Fixed cost}

a) Depreciation, $\mathrm{Rs} / \mathrm{h}$

$D=\frac{\mathrm{C}-\mathrm{S}}{L \times H}$

B. Interest, Rs/h

$I=\frac{\mathrm{C}+\mathrm{S}}{2} \times \frac{\mathrm{i}}{H}$

C. Insurance, tax and housing cost Rs/h: $3 \%$ of purchase price

B. Variable cost

a) Repair and maintenance, $\mathrm{Rs} / \mathrm{h}: 2.5 \%$ of purchase price

b) Fuel cost, Rs/h : Fuel price $(\mathrm{Rs} / \mathrm{l}) \times$ Fuel consumption $(\mathrm{l} / \mathrm{h})$

c) Lubricants cost, Rs/h: $30 \%$ of fuel cost

d) Operator or labour cost, Rs/h: Number of day $\times$ Operator charges (Rs/day)

C. Total operating cost, Rs/h: Total fixed cost +Total variable cost

Where, $\mathrm{C}$, the initial cost of the machine, Rs; $\mathrm{S}$, salvage value, @ 10\% of C; L, life of the machine, year; H, annual use, Hour and $\mathrm{I}$, interest rate. The cost economics of self-propelled was estimated by the following assumptions shown in Table 3

Table 3: Assumptions of self-propelled for cost economics

\begin{tabular}{|c|c|}
\hline Total initial cost (Rs.) & $\mathbf{1 , 8 2 , 0 0 0}$ \\
\hline Expected life of machine (year) & 10 \\
\hline Annually use of machine (days) & 30 \\
\hline Fuel cost (Rs.) & 80 \\
\hline Operating cost (Rs.) & 300 \\
\hline
\end{tabular}
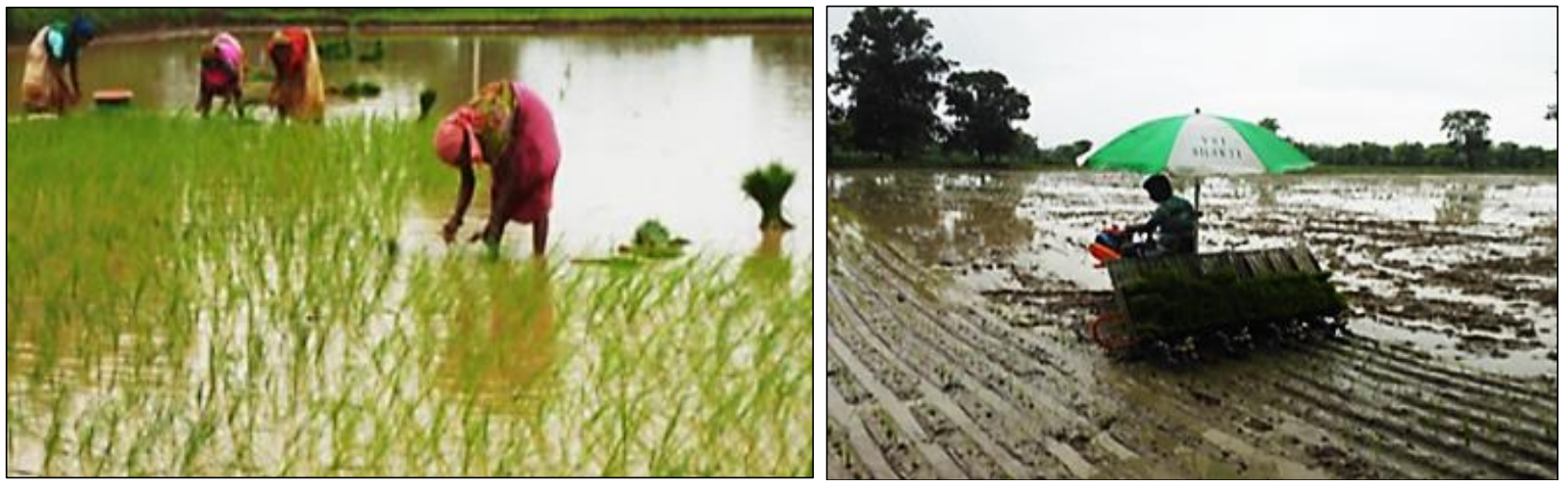

Fig 1: Transplanting of rice in manual and mechanical method 


\section{Results and Discussion}

The performance of the self-propelled rice transplanter was done in Sonpur village. The area of the experiment was 0.8 ha and performance was conduct in leveled and well-puddled field. The actual field capacity of the machine was found at $0.21 \mathrm{ha} / \mathrm{h}$. the other parameters of the field test of machine are shown in Table 4.

The energy analysis of different methods of rice transplanting was estimated and compared. The total energy consumption by self-propelled transplanter is $210 \mathrm{MJ} / \mathrm{ha}$ and by manually energy consumption is $470 \mathrm{MJ} /$ ha shown in Table 5 . In the manual method, there was no indirect energy used in the process of transplanting. The energy consumption of selfpropelled transplanter has included energy consumption by fuel energy, the total human hour for the operation of selfpropelled and included machine own energy.

Table 4: Field test data of self-propelled rice transplanter

\begin{tabular}{|c|c|c|}
\hline Sr. No & \multicolumn{2}{|c|}{ Parameters } \\
\hline 1 & Total study area, (ha) & 0.8 \\
\hline 2 & Speed of operation, $(\mathrm{km} / \mathrm{h})$ & 1.433 \\
\hline 3 & Actual field capacity, (ha/h) & 0.21 \\
\hline 4 & Theoretical field capacity, (ha/h) & 0.27 \\
\hline 5 & Field efficiency $(\%)$ & 77.79 \\
\hline 6 & Labour required, (man-days/ha) & 6 \\
\hline 7 & Fuel consumption, $(\mathrm{l} / \mathrm{h})$ & 0.522 \\
\hline
\end{tabular}

The manually process was engaged 30 labours to cover 1 ha area for rice transplanting. That means 240 man-hours was consumed for covering the area of cultivation (Dave et al., 2000) ${ }^{[5]}$. Manually process consumed more time and more energy than self-propelled. It also has many limitations like planting laborers can suffer from back problems (health risk), difficult to get enough labor at peak periods to plant on time and difficult to maintain optimum spacing and uniform plant density, especially with random transplanting and contract labor.

Table 5: Energy inputs of mechanical and manual transplanting operation

\begin{tabular}{|c|c|c|}
\hline Parameters & $\begin{array}{c}\text { By Self-propelled } \\
\text { (MJ/ha) }\end{array}$ & $\begin{array}{c}\text { By Manually } \\
\text { (MJ/ha) }\end{array}$ \\
\hline Total Fuel Energy & 47 & - \\
\hline Total Indirect Energy & 47 & - \\
\hline Human Energy & 10 & 470 \\
\hline Machine Energy & 153 & - \\
\hline Total Direct energy & 163 & 470 \\
\hline Total & 210 & 470 \\
\hline
\end{tabular}

The use of self-propelled transplanter provides economic benefits to the farmers over the manual transplanting methods because the total energy required for complete operation for transplanting with self-propelled was less than manually process. The operation with self-propelled consume less energy means less afford that can decrease the time and cost of the operation and save the energy of the farmers.

The economics of the mechanical rice transplanting and manually rice transplanting was calculated. The manual rice transplanting method is taken $240 \mathrm{~h}$ for covering the area of one hectare as compared to the self-propelled is taken $4.76 \mathrm{~h}$. The labour charge for transplanting has Rs. 200 per day and driver charges Rs. 300 per day was taken. The variable cost and fixed cost are shown in Table 6.
Table 6: Cost economics of mechanical and manual rice transplanting

\begin{tabular}{|c|c|c|}
\hline Particular & $\begin{array}{c}\text { By Self-propelled } \\
\text { (Rs) }\end{array}$ & $\begin{array}{c}\text { By manually } \\
\text { (Rs) }\end{array}$ \\
\hline Fixed Cost & 133 & \\
\hline Variable Cost & 108 & 25 \\
\hline Total Cost per hour & 241 & 25 \\
\hline Total Cost per hectare & 1145 & 6000 \\
\hline
\end{tabular}

\section{Conclusions}

The observation of the results shown that the energy consumption of the manually rice transplanting is more than double than self-propelled transplanting or mechanically transplanting method. As well as the cost of the transplanting is $81 \%$ lower in the self-propelled rice transplanting method. Results showed that the manually rice transplanting is a highly time-consuming process and more labour is required. In the peak season period, the availability of enough labour could very difficult. The result concluded that for improving our farmer's profitability and doubling the income in agricultural the mechanization must be required.

\section{References}

1. Indian Council of Agricultural Research (ICAR). Vision 2030. Indian Council of Agricultural Research, New Delhi, 2010.

2. Singh JM. On farm use pattern in different cropping systems in Haryana, India. M.S. thesis. Int. Inst. of Manage. Univ. of Flensburg, Flensburg, Germany, 2002.

3. Alam MS, Alam MR, Islam KK. Energy flow in agriculture: Bangladesh. American Journal of Environmental Sciences. 2005; 1(3):213-220. Doi:10.3844/ajessp.2005.213.220.

4. Guru PK, Chhuneja NK, Dixit A, Tiwari P, Kumar A. Mechanical transplanting of rice in India: status, technological gaps and future thrust. Oryza. 2018; 55(1):100-106.

5. Dave AK, Thakare SK, Shahare PU. Report on Status and Strategies of Farm Mechanization in Rajasthan. Department of Farm Machinery and Power Engineering College of Technology and Engineering, Maharana Pratap University of Agriculture and Technology, Udaipur313001, 2000

6. Pradhan P, Naik PK, Sahu M, Thakur C. A Study on the Energy use Pattern and Cost of Production under Transplanted Paddy Production System in Chhattisgarh, India. International Journal of Engineering Research And, 2015, V4(07). https://doi.org/10.17577/ijertv4is070812

7. Kumar U, Thakurz TC. Performance evaluation of a conventional field baler for collecting paddy straw after combining. Agricultural Engineering Today. 2006; 30(5\&6): 16-24.

8. Mobtaker HG, Keyhani A, Mohammadi A, Rafiee S, Akram A. Agriculture, Ecosystems and Environment Sensitivity analysis of energy inputs for barley production in Hamedan Province of Iran. "Agriculture, Ecosystems and Environment". 2010; 137(3-4):367-372. https://doi.org/10.1016/j.agee.2010.03.011

9. Beheshti Tabar I, Keyhani A, Rafiee S. Energy balance in Iran's agronomy (1990-2006). Renewable and Sustainable Energy Reviews, 2010.

https://doi.org/10.1016/j.rser.2009.10.024

10. Nguyen HV, Nguyen CD, Tran TV, Hau HD, Nguyen NT, Gummert M. Energy efficiency, greenhouse gas 
emissions, and cost of rice straw collection in the mekong river delta of vietnam. Field Crops Research. 2016; 198:16-22. https://doi.org/10.1016/j.fcr.2016.08.024

11. Jain A, Chaudhary JL, Beck MK, Kumar L. Developing regression model to forecast the rice yield at Raipur condition. Journal of Pharmacognosy and Phytochemistry. 2019; 8(1):72-76.

12. Kamboj, Parminder, Khurana R, Dixit A. "Farm Machinery Services Provided by Selected Cooperative Societies". Agricultural Engineering International: CIGR Journal. 2012; 14(4):123-33. 